\title{
Comparison of body mass index among schoolgirls in Catamarca as per anthropometric, self-report and figure rating scale techniques
}

\author{
Clarisa I. Rodríguez, B.S. and MSc ${ }^{a}$ Estefanía Castillo-Viera, M.D. ${ }^{b}$ and \\ Félix Arbinaga, M.D. ${ }^{b}$
}

\begin{abstract}
Objective. To compare mean weight, height, and body mass index (BMI) values as per different measurement techniques and analyze the influence of socioeconomic level and school type. Methods. Cross-sectional, descriptive study in a sample of 856 schoolgirls aged $15-18$ years attending secondary school in the city of Catamarca. Assessment included weight and height measurement, self-reported weight and height, and Stunkard's Figure Rating Scale. Socioeconomic level was assessed based on the Family Affluence Scale. Student's t tests were used for both independent and paired samples to analyze BMI measurement techniques and school type classification, and a one-way analysis of variance was used for the socioeconomic level. Pearson's correlation and linear regressions were established.

Results. Height was overestimated $(p<0.001)$ when self-reported compared to the anthropometric measurement. In relation to actual BMI, the self-report and body figure perception techniques showed significant differences $(p<0.001)$. No differences were established in terms of weight and BMI by schoolgirls' socioeconomic level. Girls who attended private schools were taller $(p=0.004)$; such difference was alsoobserved in self-reported height $(p<0.001)$. Excess weight was observed in $29.2 \%$ of schoolgirls. Conclusion. BMI estimations varied depending on the technique, and actual BMI was underestimated.

Key words: body mass index, self-report, anthropometry, schoolgirls, socioeconomic status.
\end{abstract}

a. Chair of Exercise Physiology I and Extension Program to Exercise Physiology II, School of Health Sciences, Universidad Nacional de Catamarca Argentina.

b. Universidad de Huelva, Spain.

E-mail address:

Clarisa I. Rodríguez:

clarisa_unca@hotmail.com

http: / / dx.doi.org/10.5546/ aap.2019.eng.e218

To cite: Rodríguez CI, Castillo-Viera E, Arbinaga F. Comparison of body mass index among schoolgirls in Catamarca as per anthropometric, self-report and figure rating scale techniques. Arch Argent Pediatr 2019;117(3):e218-e223.

\section{INTRODUCTION}

Although an anthropometric measurement of body mass index (BMI) made by a trained individual is the most accurate and reliable technique, BMI may be estimated using other techniques, such as body figure self-perception with the Figure Rating Scale (FRS) or self-reported weight and height, which will provide a closer approach to BMI. ${ }^{1}$

Articles published to date highlight that age, sex, social status or ethnic origin have, to a certain extent, an effect on the reliability of reported data. ${ }^{2}$ In general, in terms of perception, youth are more accurate than adults; men, than women; and underweight adolescents, than those with overweight or obesity. ${ }^{3,4}$ It appears that individuals with a high socioeconomic status know their body size better than those with a lower socioeconomic status; and disagreements are observed between subjects of different ethnic origins. ${ }^{5}$

There is still no consensus among the various authors on which of the two estimation techniques is more accurate; both are described as inexpensive, easy to use, and offering the possibility of collecting data in large populations. ${ }^{6}$ Therefore, it is common to find studies using different methods. Thus, while some studies considered only self-reported weight and height to estimate BMI, ${ }^{2,7-}$ ${ }^{9}$ others used the FRS; ${ }^{10,11}$ others combined the FRS and actual or anthropometric BMI ${ }^{12,13}$ or actual and self-reported BMI; ${ }^{1,5,6,14}$ and, lastly, some studies used the three methods. ${ }^{2}$

Most studies included in scientific literature reviews reported a systematic overestimation of height, 
an underestimation of weight, and, as a result, an altered BMI, which may be underestimated when using self-reports and self-perception based on the FRS. ${ }^{2,3,7,8,15}$ In some cases, the result was overestimated. ${ }^{11}$

The objective of this study was to compare mean weight, height, and BMI values as per different measurement techniques and analyze the influence of socioeconomic level and school type.

\section{METHODS}

This was a non-experimental, cross-sectional, correlational-causal study. It was conducted between May and August 2017.

The sample was selected in a probabilistic (stratified) fashion and was made up of schoolgirls attending $4^{\text {th }}, 5^{\text {th }}$, and $6^{\text {th }}$ year of secondary school in the city of Catamarca. Every secondary school in the city was invited to participate.

In relation to ethical aspects, the considerations of the Declaration of Helsinki were followed. Schoolgirls' assent and parents' informed consent were obtained before data collection. The study protocol was approved by the Provincial Directorate of Secondary Schools and the Provincial Coordination of Physical Education.

The inclusion criteria were voluntary participation of schoolgirls who attended school on the day of assessment and who submitted the authorization signed by their legal tutors. Schoolgirls who were older than 18 years, pregnant and/or had eating disorders were excluded.

Socio-anthropometric information was collected using a specially designed questionnaire (age, class, school type [public/private], date of birth, self-reported and measured weight and height).

The anthropometric measurement was performed by a level II anthropometrist of the International Society for the Advancement of Kinanthropometry (ISAK) ${ }^{16}$ during physical education classes, where adolescents had to be wearing short tights and a sports bra or top.

Weight was assessed using an OMRON HBF-214LA digital scale, whereas height was measured using an acrylic wall stadiometer by Calibres Argentinos.

BMI was established based on the weight $(\mathrm{kg}) /$ height $\left(\mathrm{m}^{2}\right)$ formula. To assess BMI perception, the Stunkard and Stellar test (1990) was used, as adapted into Spanish by Marrodán
(2008), which included nine silhouettes with their corresponding BMI.

Socioeconomic level was assessed based on the Family Affluence Scale (FAS), developed by Boyce (2006) and validated in adolescents, considering it was a measure of a household financial capital that included known validity coefficients and allowed to assess a family socioeconomic level. The FAS score was estimated based on questionnaire answers (four elements), with a minimum of 0 and a maximum of 9 points. It indicated a low $($ score $=0,1,2)$, middle (score $=3,4,5$ ) or high financial affluence (score $=6,7,8,9)$.

Data analysis: A descriptive analysis of results was done in the first place (frequency, percentage, mean, standard deviation, maximum and minimum values). For the inferential analysis, mean contrast tests were done using Student's $t$ test for paired and independent samples and their corresponding Cohen's d effect size ("small" effect: size between 0.2 and 0.3 ; "medium" effect: size of approximately 0.5 ; and a "large" effect: size from 0.8 to infinite). ${ }^{17}$ Socioeconomic level was analyzed using a one-way analysis of variance (ANOVA). The $\chi^{2}$ test was estimated to establish the contrast between categorical outcome measures. Pearson's correlation and linear regressions were established to analyze the relation or dependence of studied outcome measures.

The SPSS 22.0 software package for Windows was used.

\section{RESULTS}

A total of 856 schoolgirls participated in the study; $\mathrm{n}=541-67.86 \%$ - attended public schools and $\mathrm{n}=315-32.14 \%-$, private schools; participants accounted for $18.6 \%$ of all female students attending the last three years of the city's secondary schools, as per data obtained from the website of the Provincial Ministry of Education, Science, and Technology of Catamarca based on education statistics for 2016.

By reviewing the socioeconomic level, it was determined that $78.78 \%$ of students of low socioeconomic level, $60.52 \%$ of middle socioeconomic level, and $36.36 \%$ of high socioeconomic level attended public schools. The $\chi^{2}$ test established that, at a $5 \%$ significance level $\left(\chi_{(2.856)}^{2}=88.066, p<0.001\right)$, the socioeconomic level was related to schools; therefore, schoolgirls who belonged to a high socioeconomic status tended to attend private schools, with a Cramer's V test for effect size $=0.321$. 
The analysis of measured height showed that private school female students were taller than those who attended public schools $(p=0.004)$. Likewise, such differences were observed in selfreported height $(p<0.001)$ (Table 1).

Comparing weight and height based on both techniques, differences in measured and selfreported weight were observed, which translated into an underestimation of weight by $0.586 \mathrm{~kg}$. Differences in measured and self-reported height were also observed $(p<0.001)$, so it was inferred that height was overestimated by $0.005 \mathrm{~m}$.

The correlation coefficient analysis established high correlations for both outcome measures: measured versus self-reported height $(r=0.806)$, measured versus self-reported weight $(r=0.909)$. A regression analysis showed that self-reported height and weight may predict measured height and weight by $80.6 \%$ and $90.9 \%$, respectively.

To determine BMI, sample data were adjusted to the group's mean age ( $c=15.99$ years). Based on this, and according to the child growth standards published by the World Health Organization (WHO, 2007) ${ }^{18}$ for children and adolescents aged 5-19 years, the corresponding values for all percentiles were established (P5, malnutrition: $\leq 16.77 \mathrm{~kg} / \mathrm{m}^{2} ;$ P5-P85, normal weight: 16.78 to $24.65 \mathrm{~kg} / \mathrm{m}^{2}$; P85-P95, overweight: 24.66 to $28.89 \mathrm{~kg} / \mathrm{m}^{2}$; and P97, obesity: $\geq 28.90 \mathrm{~kg} / \mathrm{m}^{2}$ ).

The mean BMI, either actual or anthropometric, of schoolgirls in the sample was $23.30 \mathrm{~kg} / \mathrm{m}^{2}( \pm 4.86)$, with a minimum of $14.93 \mathrm{~kg} / \mathrm{m}^{2}$ and a maximum of $54.08 \mathrm{~kg} / \mathrm{m}^{2}$.

Based on the anthropometric technique, most schoolgirls had a normal weight $(68.6 \%)$, whereas $17.2 \%$ were overweight, $12 \%$ were obese, and $2.2 \%$ suffered malnutrition (Table 2).

The analysis of Pearson's correlation coefficient for actual BMI/self-reported BMI established an $\mathrm{r}$ value $=0.841(p<0.001)$; the actual BMI/ perceived BMI based on body figure perception showed an $r=0.745(p<0.001)$. In both cases, this indicated high, positive, and significant correlations.

The linear regression analysis showed that the relation and the predictive value of self-reported BMI and that based on body figure perception were high, which resulted in a possibility of predicting actual BMI with both techniques of $84.1 \%$ and $74.5 \%$, respectively.

An analysis of the three measurement techniques (actual, self-reported, and body figure perception) in relation to BMI mean values (Table 3) determined that self-report and body figure perception showed significant differences $(p<0.001)$ between each other and versus the anthropometric technique.

The one-way ANOVA showed that, in terms of BMI, as estimated by the three techniques and according to the socioeconomic level categories (FAS), schoolgirls who had a low or middle socioeconomic level were more commonly overweight $(7.1 \%, 6.9 \%$, and $3.2 \%$, respectively) and obese $(5.0 \%, 5.1 \%$, and $1.9 \%)$ than those who had a high socioeconomic level, although differences were not significant $(p=0.390)$. The analysis by type of school indicated that only the body figure perception showed significant differences $(p=0.021)$, with an effect size of 0.167 (Table 4).

\section{DISCUSSION}

The objective of this study was to compare mean weight, height, and BMI values as per different methodologies and analyze the influence of socioeconomic level and school type.

In order to establish if schoolgirls' socioeconomic level was related to outcome measures (weight, height, and BMI), first of all it is necessary to explain that socioeconomic classification was not done for study population stratification purposes but to find out if

TABLE 1. Mean and standard deviation for weight $(\mathrm{kg})$ and height $(\mathrm{m})$ based on measurement techniques

\begin{tabular}{lcccccc}
\hline & Total $(\mathbf{n}=\mathbf{8 5 6})$ & Pub. sc. $(\mathbf{n}=\mathbf{5 4 1})$ & Pri. sc. $(\mathbf{n}=\mathbf{3 1 5})$ & $\boldsymbol{t}$ & $\boldsymbol{p}$ & Cohen's $\boldsymbol{d}$ \\
\hline Age & $15.99 \pm 0.91$ & $15.98 \pm 0.93$ & $16.01 \pm 0.87$ & 0.39 & 0.694 & \\
Mea. weight & $59.83 \pm 13.47$ & $59.62 \pm 13.01$ & $60.19 \pm 14.26$ & 0.60 & 0.549 & \\
SR weight & $59.24 \pm 12.04$ & $58.84 \pm 11.68$ & $59.94 \pm 12.62$ & 1.29 & 0.198 & \\
Mea. height & $1.60 \pm 0.06$ & $1.59 \pm 0.60$ & $1.61 \pm 0.06$ & 2.87 & $0.004^{*}$ & 0.331 \\
SR height & $1.61 \pm 0.07$ & $1.59 \pm 0.08$ & $1.62 \pm 0.07$ & 4.57 & $0.001^{* *}$ & 0.328 \\
\hline
\end{tabular}

* The mean difference is significant at the 0.05 level and at the $<0.001$ level. Student's $t$ test for independent samples. SD: standard deviation; Pub. sc.: public school; Pri. sc.: private school; Mea. weight: measured weight; SR weight: self-reported weight; Mea. height: measured height; SR height: self-reported height. 
socioeconomic inequalities affected schoolgirls' body perception and the prevalence of overweight and obesity.

In relation to the study's objective, it was observed that schoolgirls overestimated height and underestimated weight; therefore, the selfreported BMI was also underestimated compared to actual BMI. These results were consistent with those obtained in other studies conducted in adolescents. ${ }^{4,715}$

Considering that there is a worldwide trend towards excess weight, in Argentina, the
Ministry of Health ${ }^{19}$ reported that the prevalence of overweight and obesity increased among adolescents between 2007 and 2012, from $17.9 \%$ to $27.8 \%$, and from $3.2 \%$ to $6.1 \%$, respectively. Therefore, study reports from 5 to 10 years $\mathrm{ago}^{20-25}$ may be outdated compared to the actual circumstances in each country.

According to the data obtained from a secondary study as part of the 2012 Worldwide Survey on School Health (Encuesta Mundial de Salud Escolar, EMSE) ${ }_{1}^{19}$ conducted in Argentina by the National Ministry of Health, schoolchildren

TABLE 2. Mean and standard deviation for nutritional status based on body mass index $\left(\mathrm{kg} / \mathrm{m}^{2}\right)$ according to different measurement techniques

\begin{tabular}{|c|c|c|c|c|}
\hline \multirow[t]{2}{*}{ BMI } & $\begin{array}{c}\text { Malnutrition } \\
\text { n }(\%)\end{array}$ & $\begin{array}{c}\text { Normal weight } \\
\text { n }(\%)\end{array}$ & $\begin{array}{c}\text { Overweight } \\
\text { n }(\%)\end{array}$ & $\begin{array}{l}\text { Obesity } \\
\text { n }(\%)\end{array}$ \\
\hline & $\chi \pm \mathrm{SD}$ & $\chi \pm \mathrm{SD}$ & $\chi \pm \mathrm{SD}$ & $\chi \pm \mathrm{SD}$ \\
\hline Actual BMI & $\begin{array}{c}19(2.2) \\
16.28 \pm 0.49\end{array}$ & $\begin{array}{c}587(68.6) \\
20.98 \pm 1.92\end{array}$ & $\begin{array}{c}147(17.2) \\
26.44 \pm 1.22\end{array}$ & $\begin{array}{c}103(12) \\
33.35 \pm 4.29\end{array}$ \\
\hline SR BMI & $\begin{array}{c}26(3) \\
15.76 \pm 0.69\end{array}$ & $\begin{array}{c}599(70) \\
21.09 \pm 1.94\end{array}$ & $\begin{array}{c}144(16.8) \\
26.28 \pm 1.13\end{array}$ & $\begin{array}{c}87(10.2) \\
32.42 \pm 3.59\end{array}$ \\
\hline BMI BFP & $\begin{array}{c}117(13.7) \\
17 \pm 0.11\end{array}$ & $\begin{array}{c}696(81) \\
21.66 \pm 1.84\end{array}$ & $\begin{array}{c}32(3.6) \\
27 \pm 0.13\end{array}$ & $\begin{array}{c}14(1.6) \\
30.43 \pm 2.83\end{array}$ \\
\hline
\end{tabular}

BMI: body mass index; SD: standard deviation; SR BMI: self-reported body mass index;

BMI BFP: body mass index as per body figure perception. One-way ANOVA.

TABLE 3. Differences in mean body mass index $\left(\mathrm{kg} / \mathrm{m}^{2}\right)$ by measurement technique

\begin{tabular}{|c|c|c|c|c|c|c|c|c|c|c|}
\hline & \multirow[b]{2}{*}{$\chi$} & \multirow[b]{2}{*}{$\mathbf{N}$} & \multirow[b]{2}{*}{ SD } & \multicolumn{2}{|c|}{ REL. DIFF. } & \multicolumn{2}{|c|}{$95 \% \mathrm{CI}$} & \multirow[b]{2}{*}{$t$} & \multirow[b]{2}{*}{ df } & \multirow[b]{2}{*}{ Sig. (bil) } \\
\hline & & & & $\chi$ & SD & Lower & Upper & & & \\
\hline Actual BMI & 23.30 & 856 & 4.86 & 0.347 & 2.65 & 0.169 & 0.525 & 3.84 & 855 & 0.000 \\
\hline$\underline{\text { SR BMI }}$ & 22.95 & 856 & 4.38 & & & & & & & \\
\hline Actual BMI & 23.30 & 856 & 4.86 & 1.94 & 3.34 & 1.71 & 2.16 & 16.99 & 855 & 0.000 \\
\hline BMI BFP & 21.36 & 856 & 2.83 & & & & & & & \\
\hline SR BMI & 22.95 & 856 & 4.38 & 1.59 & 3.25 & 1.71 & 2.16 & 14.31 & 855 & 0.000 \\
\hline BMI BFP & 21.36 & 856 & 2.83 & & & & & & & \\
\hline
\end{tabular}

* The mean difference is significant at the < 0.001 level. Student's $t$ test for related samples. SD: standard deviation; SR BMI: self-reported body mass index; BMI BFP: body mass index as per body figure perception. REL. DIFF.: relative difference. CI: confidence interval.

TABLE 4. Mean and standard deviation for body mass index $\left(\mathrm{kg} / \mathrm{m}^{2}\right)$ as per measurement technique and school type

\begin{tabular}{lccccc}
\hline $\boldsymbol{X} \pm$ SD & $\begin{array}{c}\text { Total } \\
(\mathbf{n}=\mathbf{8 5 6})\end{array}$ & $\begin{array}{c}\text { Public school } \\
(\mathbf{n}=\mathbf{5 4 1 - 6 7 . 8 6} \%)\end{array}$ & $\begin{array}{c}\text { Private school } \\
(\mathbf{n}=\mathbf{3 1 5 - 3 2 . 1 4} \%)\end{array}$ & $\boldsymbol{t}$ & $\mathbf{p}$ \\
\hline Actual BMI & $23.30 \pm 4.86$ & $23.35 \pm 4.73$ & $23.21 \pm 5.09$ & 0.41 & 0.685 \\
SR BMI & $22.95 \pm 4.38$ & $23.04 \pm 4.30$ & $22.79 \pm 4.51$ & 0.79 & 0.427 \\
BMI BFP & $21.36 \pm 2.83$ & $21.18 \pm 2.68$ & $21.66 \pm 3.05$ & 2.31 & $0.021^{*}$ \\
\hline
\end{tabular}

* The mean difference is significant at the 0.05 level. Student's $t$ test for independent samples. SD: standard deviation; SR BMI: self-reported body mass index; BMI BFP: body mass index as per body figure perception. 
with a low socioeconomic level had $31 \%$ more chances of developing overweight than those with a high socioeconomic level.

Another study conducted in 28368 male and female adolescents aged 11-17 years, which was funded by UNICEF Argentina and carried out by investigators of Fundación Interamericana del Corazón (FIC), ${ }^{26}$ reported differences between low and high socioeconomic level in terms of overweight and obesity of $29.6 \%$ and $6.7 \%$, respectively, versus $25.3 \%$ and $4.3 \%$ (without breaking them down by sex), and this was consistent with the results of this study, which showed that overweight and obesity were higher among low socioeconomic level populations (11.4\% versus $5.7 \%$ and $7.5 \%$ versus $4.6 \%$, respectively). Although the percentages observed in our study were lower, this may be due to different factors: number of participants, sex, age or even the scale chosen for sample stratification (parental level of education). The data provided by this study are consistent with those reported in previous investigations. ${ }^{21,26}$

On the contrary, other authors $\mathrm{s}^{27,28}$ have reported a higher prevalence of overweight and obesity among women in populations with a higher socioeconomic level, but it should be noted that most studies' assessment criteria considered parental level of education and profession and attendance to public or private schools, ${ }^{27-29}$ whereas our study assessed socioeconomic level based on the FAS questionnaire.

In relation to the sample's BMI category, as per the WHO standards for schoolchildren, our results showed an excess weight percentage $(30 \%)$ that was similar to that observed in other studies. ${ }^{20-22}$ By contrast, other studies have reported a high malnutrition percentage. ${ }^{23-25,27}$

Some studies ${ }^{25}$ did not specify the reference standards or cutoff points used for each BMI category; others used standards that were different from those established by the WHO (2007) for children and adolescents.. ${ }^{20-22}$ Therefore, it would not be honest to compare our results to those mentioned above because they would not be describing the same reality in the practical sense of BMI classification.

BMI established based on body figure perception showed a clear body image distortion; only $52.38 \%$ of schoolgirls had shown agreement between actual and perceived BMI. According to our results, this technique underestimated BMI, whereas other studies have observed an actual BMI overestimation and only a small underestimation percentage. 5,13

In general, the two techniques (self-report and body figure perception) underestimated BMI compared to actual BMI, and this was higher for body figure perception. ${ }^{15}$

The strengths of this study were its sample size and the discrimination based on the type of school (public/private). The limitations include the need to perform assessments in schoolboys and extend the age range. Likewise, it is necessary to develop a methodology that helps to clarify or explain the determining relations among the different assessment techniques.

This was a cross-sectional study conducted in a population of female adolescents, so its results may serve as the baseline for qualitative, longitudinal or mixed investigations that extend the age range of the population, so that they would favor the study process and the development of new approaches to this health problem that increasingly affects more students.

\section{CONCLUSIONS}

In this study, schoolgirls showed differences in BMI estimation as per the different measurement techniques, and actual BMI was underestimated.

\section{REFERENCES}

1. Sosa JCS, de la Rubia JM, Cantú Martínez PC. El índice de masa corporal autorreportado como medida antropométrica pertinente en estudios de imagen corporal. RESPYN. 2008; 9(4).

2. Stommel M, Schoenborn CA. Accuracy and usefulness of BMI measures based on self-reported weight and height: findings from the NHANES \& NHIS 2001-2006. BMC Public Health. 2009; 9:421.

3. Krul AJ, Daanen HA, Choi H. Self-reported and measured weight, height and body mass index (BMI) in Italy, the Netherlands and North America. Eur J Public Health. 2011; 21(4):414-9.

4. Vaquero-Cristóbal R, Alacid F, Muyor JM, López-Miñarro PA. Imagen corporal: revisión bibliográfica. Nutr Hosp. 2013; 28(1):27-35.

5. Marrodán MD, Martínez-Álvarez JR, Villarino A, AlférezGarcía I, et al. Utilidad de los datos antropométricos autodeclarados para la evaluación dela obesidad en la población española; estudio EPINUT-ARKOPHARMA. Nutr Hosp. 2013; 28(3):676-82.

6. Shields M, Connor Gorber S, Tremblay MS. Estimates of obesity based on self-report versus direct measures. Health Rep. 2008; 19(2):61-76.

7. Brettschneider AK, Rosario AS, Ellert U. Validity and predictors of BMI derived from self-reported height and weight among 11-to 17-year-old German adolescents from the KiGGS study. BMC Res Notes. 2011; 4:414.

8. MerrillRM, Richardson JS. Validity of Self-Reported Height, Weight and Body Mass Index: Findings from the National Health and Nutrition Examination Survey, 2001-2006. Prev Chronic Dis. 2009; 6(4):A121.

9. López Sánchez GF, Díaz Suárez A, Smith L. Análisis de 
imagen corporal y obesidad mediante las siluetas de Stunkard en niños y adolescentes españoles de 3 a 18 años. An Psicol. 2018; 34(1):167-72.

10. Alcaraz López G, Lora Gómez E, Berrio Estrada ME. Índice de masa corporal y percepción de la imagen corporal en estudiantes de enfermería. Index Enferm. 2011;20(1-2):11-5.

11. González-Montero M, André AL, García-Petuya E, LópezEjeda N, et al. Asociación entre actividad física y percepción de la imagen corporal en adolescentes madrileños. Nutr Clin Diet Hosp. 2010; 30(3):4-12.

12. Muñoz-Cachón MJ, Salces I, Arroyo M, Ansotegui L, et al. Overweight and obesity: prediction by silhouettes in young adults. Obesity (Silver Spring). 2009; 17(3):545-9.

13. Oliva-Peña Y,Ordóñez-Luna M,Santana-Carvajal A,MarínCárdenas $\mathrm{AD}$, et al. Concordancia del IMC y la percepción de la imagen corporal en adolescentes de una localidad suburbana de Yucatán. Rev Biomed. 2016; 27(2):49-60.

14. Fonseca H, Silva AM, Matos MG, Esteves I, et al. Validity of BMI based on self-reported weight and height in adolescents. Acta Paediatr. 2010; 99(1):83-8.

15. Sánchez-Álvarez M, González-Montero M, Marrodán MD. Comparación entre el Índice de Masa Corporal autoreferido auto-percibido y antropométrico en adolescentes madrileños. Antropo. 2012; 26(1):91-7.

16. Sociedad Internacional para el Avance de la Cineantropometría (ISAK). [Accessed on: March 30 ${ }^{\text {th }}$, 2018]. Available at: https:/ / www.isak.global/.

17. CohenJ.Statistical power analysis for the behavioral sciences. 2 ed. Hillsdale, NJ: LEA; 1988.

18. De Onis M, Onyango AW, Borghi A, Siyam A, et al. Development of a WHO growth reference for school-aged children and adolescents. Bull World Health Organ. 2007; 85(9):660-7.

19. Argentina Ministerio de Salud. Alimentación saludable, Sobrepesoy obesidad en Argentina. [Accessed on: February $19^{\text {th }}$, 2018]. Availableat:http:/ / www.msal.gob.ar/images/ stories / ryc/graficos / 0000001137cnt-2017-09_cuadernilloobesidad.pdf.

20. Cruz Sáez MS, Salaberria K, Rodríguez S, Echeburúa E. Imagen corporal y realización de dieta: diferencias entre adolescentes españolas y latinoamericanas. Universitas Psychologica. 2013; 12(3).

21. Jiménez-Aguilar A, Flores M, Shamah-Levy T. Sugarsweetened beverages consumption and BMI in Mexican adolescents: Mexican National Health and NutritionSurvey 2006. Salud Pública Mex. 2009; 51(Suppl 4):S604-12.

22. Altamirano Martínez MB, Vizmanos Lamotte B, Unikel Santoncini C. Continuo de conductas alimentarias de riesgo en adolescentes de México. Rev Panam Salud Pública. 2011; 30(5):401-7.

23. Pereira PMdeL, Do Carmo CC, Cândido APC. Identificação da insatisfação corporal e comportamentos favoráveis ao desenvolvimento de transtornos alimentares em adolescentes de uma escola pública. Adolesc Saúde. 2013; 10(4):33-40.

24. Herazo AcevedoE, Villamil Vargaz M. Concordancia entre la autopercepción de peso y el índice de masa corporal en adolescentes. Rev Salud Pública. 2012; 14(6):1043-8.

25. Yepez R, Carrasco F, Baldeón ME. Prevalencia de sobrepeso $\mathrm{y}$ obesidad en estudiantes adolescentes ecuatorianos del área urbana. Arch Latinoam Nutr. 2008; 58(2):139-43.

26. Ponce M, Allemandi L, Castronuovo L, Tiscornia V, SchojV. Brechas sociales en la obesidad en la niñez y adolescencia: Análisis de la Encuesta mundial de Salud Escolar (EMSE) Buenos Aires: UNICEF; 2016. [Accessed on: February 19 ${ }^{\text {th }}$, 2018]. Available at: https: / /www.unicef.org/argentina / sites / unicef.org.argentina / files / 2018-03/Salud_UInformeObesidad2016ok.pdf.

27. Borda Pérez MD, Celemín Nieto A, Celemín Nieto A, Palacio L, Majul F. Bulimia nerviosa y factores de riesgo asociados en adolescentes escolarizados de 14 a 18 años en Barranquilla (Colombia). Salud Uninorte. 2015; 31(1):36-52.

28. Gotthelf SJ, Jubany LL. Prevalencia de factores de riesgo cardiovascular en adolescentes de escuelas públicas y privadas de la ciudad de Salta, año 2009. Arch Argent Pediatr. 2010; 108(5):418-26.

29. Cano Garcinuño A, Alberola López S, Casares Alonso I, Pérez García I. Desigualdades sociales en la prevalencia de sobrepeso y obesidad en adolescentes. An Pediatr (Barc). 2010; 73(5):241-8. 